\title{
Corporation as a Social and Legal Institution: An Analytical Review of Russian Historiography
}

\author{
Valeryi A. Letyaev ${ }^{1} \&$ Tatyana K. Krasilnikova ${ }^{2}$ \\ ${ }^{1}$ Kazan (Volga Region) Federal University, Kazan, Russia \\ ${ }^{2}$ Volgograd State University, Voljskiy, Russia \\ Correspondence: Valeryi A. Letyaev, Kazan (Volga Region) Federal University, Kremlyovskaya street, 18, \\ Kazan 420008, Russia. E-mail: valeri.letyaev@gmail.com
}

\author{
Received: April 14, 2015 Accepted: April 20, 2015 Online Published: April 27, 2015 \\ doi:10.5539/jsd.v8n4p202 URL: http://dx.doi.org/10.5539/jsd.v8n4p202
}

\begin{abstract}
The topic under study is urgent due to the fact that the analysis of the main trends of Russian historiography in the field of corporate law will affect the optimization of the development of normative legal acts regulating the establishment and activities of corporations. The objective of the article is to reveal positive and negative stereotypes in the understanding of legal, economic and social nature of corporations, in determining their status, stability and dynamics of development. A leading research method is an integrated approach based on the unity of analysis and synthesis. The article deals with the evolution of the views of Russian scholars on the peculiarities of creation and functioning of various types of corporate associations in Russia, Russia's forms of participation in the activities of corporations from a historical perspective. The materials of the article may be useful to economists, lawyers, sociologists and historians.
\end{abstract}

Keywords: corporation, company, partnership, joint stock company, mixed society, monopolies, team, guild, workshop, corporate law

\section{Introduction}

\subsection{Urgency of the Problem}

The legal status of corporations in Russia has not been the subject of research for a long time. This can be explained by several reasons. Firstly, Russian legal science was not as interested in history of Russian companies as the other countries were. In Russia, the establishment of business corporations largely occurred under the influence of Western European practices, legislation and scientific literature. Therefore, history of Russian corporations received less attention in legal literature in Russia. Secondly, during the period of planned economy and national ownership on means of production, the Soviet Union was not interested in corporations as participants of civil commerce. The interest in Russian corporations has been growing only over the last 20 years after the adoption of the Civil Code of the Russian Federation.

\subsection{Scientific Novelty of the Research}

The novelty of the phenomenon, little knowledge about it in Russian legal science, argumentativeness of the existence of the corporation as a legal institution and corporate law as an independent branch of law generate permanent interest in the legal phenomenon. Therefore, the majority of the major issues of history and theory of corporate law in Russia remain controversial.

Corporation as a social and legal institution has not been studied from a historical point of view yet. Therefore, the proposed research fills the gap.

The article provides a retrospective analysis of the scientific views of leading Russian and foreign scholars on the legal nature of corporations, historical, socio-economic, political and legal conditions and prerequisites for the development of this institution in Russia, the state policy in the sphere of legal regulation of the establishment and the activities of various kinds of corporations at different stages of historical development of Russian society (Barsukov, 2000; Golikova, 1998; Malykhina, 2003; Sabirova, 2005; Sonkin, 1999; Stoklitskaya-Tereshkovich, 1951; Tikhomirov, 1946; Fadeev, 2004; Funk et al., 1999). 


\subsection{Theoretical Basis of the Article}

The theoretical basis of the article is made up of the works of Russian and foreign academic lawyers that dealt with various aspects of the establishment and activities of corporations in Russia (Volnyansky, 2010; Kulagin, 1987; Rukavishnikov, 2005; Serova, 2011; Fuhrmann, 1972; Owen, 1995).

To study the nature of a legal corporation the authors highlight the role of legal doctrine in order to justify by science new organizational and legal forms of corporate activities that meet the needs of socio-economic development of the country. (Wolf, 1927; Isaev, 1977; Kushniruk, 2005 Laverychev, 1982; Sabirova, 2005; Shumilina, 2009).

\subsection{Hypothesis of the Study}

There are several major periods in historiography that differ according to various methodological approaches to the study, nature of the sources involved, and level of theoretical generalizations of historical facts.

In modern Russian legal and economic literature corporations are mainly defined as complex economic structures, known, as a rule, as joint-stock companies. However, the interpretation of this term does not correspond to its historically generated value. The corporation is, firstly, a collective entity with a certain kind of relationship between its members; secondly, it is a union of persons with certain rights who fulfil the duties established by this union and, thirdly, it is an organization with a specific internal structure.

Historically, not only businesses but also social and professional associations as well as public institutions, religious organizations, workshops, guilds, etc. had the status of a corporation.

The analysis shows that the development of corporate forms of association in Russia was evolutionary in character and agreed with the socio-economic, cultural and historical features of Russian society.

Detailed legal standards for corporate operations were not introduced in Russia since the concept was mainly used in science as a generic term for all associations with corporate structure.

Soviet civil law borrowed the "bourgeois experience" and classic civil structural system modifying them according to the needs of the socialist state. The system of legal entities in the post-Soviet period was formed in the time of privatization and commercialization of the Russian economy, so it was characterized by instability, lack of consistency and, in general, did not meet the principles of the system that influenced the character of studies of corporate associations in those conditions.

Individual research, conducted by historians, was objectively descriptive and related to the history of the corporate form of associations only in part, without considering corporations as a subject of research.

Nowadays study of corporations is the subject of various branches of law. Works of contemporary scholars differ significantly from the previous studies by the number of references, line of reasoning and logic of presentation. The subjects of the research were also extended.

\section{Methodological Framework}

The methodological framework of the current study is the system of techniques and methods that include historical and legal, historical and systemic, structural and functional, comparative and legal methods based on the following principles:

- principle of objectivity that ordains considering historical reality based on historical facts;

- principle of historicism which helps determine how the attitudes of scholars about the institution of corporation changed in different historical periods;

- principle of comprehensiveness which allows to make the institution a subject of study of several sciences. The issues under study are considered to be interdisciplinary, at the junction of sciences such as law, economics, sociology, which correspond to the problems of a complex analysis.

\section{Results}

\subsection{Formation of Soviet Legal Science of Corporations}

A characteristic feature of the early Soviet study of corporate law in Russia was the division of scholars into those who based their research on Marxist dogma, and those who represented the pre-revolutionary legal science. "Marxist-lawyers" put forward the idea of creating a fundamentally new law, and the lawyers of the old school tried to adapt the institution of corporation to the new conditions of the socialist economy, primarily, by defending civil positions.

The scientific debates of the 1920s gave a wealth of material which allowed to judge the theoretical views, 
positions both of scholar-lawyers and legislators, representatives of judiciary law.

A characteristic feature of Soviet civil law was the inconsistence of many principles of law which led to an increase in the role of legal doctrine. The adoption of the Civil Code of the Russian SFSR in 1922 found a response in the academic commentary of legal scholars of the time. Of particular importance in the 1920-30s in Soviet Russia and the Soviet Union were the works of H. Bakhchisaraytsev (1927), V. Volf (1927), A. Vorms (1922), S. Landkof (1924).

With the introduction in the Soviet Union in the late 1930s of a planned command economy it was necessary to justify the inefficiency of the organization and activities of corporate groups. Thus, according to G. Amfiteatrov (1930), traditional civil organizational forms had to be recognized as less effective than the 'socialised' ones.

In the 1940-70s Soviet historians and legal scholars turned to the study of medieval types of corporations. In this regard, it is important to mention the works of M. Tikhomirov (1946), B. Rybakov (1948), V. Stoklitskoy-Tereshkovich (1951), and B. Florya (1977). This was made possible by the emergence of new archival materials.

Research by the Soviet science of capitalist type corporations was still carried out with the positions of the communist ideological dogmas (Laverychev, 1984).

Features of Soviet corporations, various research, production and agricultural systems operating in the USSR in the 1970-80s attracted the attention of V. Zolotarev (1983), N. Sonkin, and T. Gromkovskaya (1989).

\subsection{New Approaches to the Study of Corporations in Russia in the Late 1990s - Early 2000s}

In the late 1990s, there was an increased interest in studying the economic, legal and social essence of the corporation; new approaches to the study of this institution were offered.

Historical and legal analysis of the process of formation of corporate management forms from the ancient times to the present day is presented in the works of M. Malykhina (2003), Ya. Funk, V. Mikhalchenko, and V. Khvaley (1999).

Among the authors who did a system research of certain types of estate-corporate companies and business corporations in Russia, N. Golikova (1998) and V. Barsukov (2000) should be pointed out. Other studies were either limited by narrow chronological framework or were based on the materials of a single city or area, or based on a study of similar sources.

In the monographic study of B. Mironov (2003) there was considered the social dynamics of the formation and development in Russia of class corporations - merchant, artisan and noble societies - from the end of the $17^{\text {th }}$ century to the early $20^{\text {th }}$ century.

Yu. Glazov (2011, 2013), considering the process of institutionalization of the organization of Russian merchants, pointed out the fact that it was a combination of the Western European model of guild organisation and Russian traditions. According to the author, due to the fact that in Russian society there did not exist Western European type classes, a Russian legislator of the $18^{\text {th }}$ century -1830 s used the concept of 'class' to refer to groups of people organized in corporations. An opposite position was taken by a historian of law Yu. Shubnikov (2002) who argued that classes in Russia played the role of a fiscal rather than a corporate institution.

From the mid-1990s to the early $21^{\text {st }}$ century economic partnerships, societies, cooperatives became the subject of research for V. Gorlov (1998), A. Kushniruk (2005), and A. Belonovskaya (2010).

V. Gorlov (1998) studied the basic stages of the development of Russian legislation for limited liability companies. In contrast to the scholars who claimed that such type of corporation had no analogues in the past (Bergman \& Komarov, 1996), V. Gorlov was able to prove that "it appeared by adjusting the already existing forms to the new needs of society" and represented a certain transitional combination of various elements of already existing comradely associations.

In 2001, several dissertations in history and legal nature of stock corporations were defended. They disclosed the role of their statutory practice in the regulation of incorporated relations (Nosov, 2001; Chernozhukov, 2001; Krasilnikova, 2001).

From the late 1990s the views of Russian scholars on the peculiarities of establishment and operation of major Russian monopolies were revised. Historical and legal studies of monopolist associations were described in the works of O. Erokhina (2009), N. Biyushkina, and D. Grachev (2007).

Functioning of foreign corporations in Russia became the subject of study in the Soviet period by N. Voznesenskaya (1989), I. Isaev (1977), in the 1990s by T. Izmestieva (1998), I. Potkina (1997), in the early $21^{\text {st }}$ 
century by N. Kurys (2003), S. Smirnov (2002).

Of particular importance for the historical and legal science and modern practice was the synthesis and analysis of the experience of legal regulation of the state's participation in the functioning of various kinds of corporations. There was revived interest in the experience of functioning of mixed companies with state participation. Of particular value are the works of N. Kurys (2003) who, in a number of studies managed to show the difficulties associated with the inaccuracies of the conceptual apparatus in the law and scientific literature that were concealed in "consideration of mixed (joint) companies". In the Soviet period the term "mixed enterprises" referred to enterprises in which state and private capital were merged with foreign capital.

In the early $21^{\text {st }}$ century there was an increased attention to the theory of corporate law. Of special note are the works of D. Volnyansky (2010), O. Serovaya (2011), and S. Rukavishnikova (2005). Thus, D. Volnyansky (2010) in his dissertation Theoretical Problems of Corporate Law of the Russian Federation, from the standpoint of historical and theoretical approach, revealed signs of a corporation, showed its universal character as a form of human organization. An integrated analysis of corporation was carried out in S. Rukavishnikov's dissertation (2005) that explores how and what influenced the terminological diversity - the difference in the use of the term 'corporation' applied to various organizational and legal forms of professional, business and other associations.

According to another researcher, O. Serovaya (2011), the system of legal entities cannot be permanent; it is supplied by the gradual transformation of contractual forms of association into a new independent type of a legal entity. The author proposed to make changes to the system of classification of types of legal entities and legalize the corporation as a separate legal entity.

G. Gurevich and S. Rokhmistrov (2004) in their monograph Corporate Governance: Origins of Formation in Russia attempted to prove that despite the fact that the first associations of corporate type go back to the period of the Middle Ages, the corporation is an "institution of industrial society". The authors gave a detailed description of the corporate form of ownership which was recognized as an analogue of socialist property in the Soviet period. This was facilitated by the fact that the corporation as a form of organization of production could be a public company.

Consideration of the corporation as a socio-political institution was the subject of scientific interest of economists, sociologists, legal scholars and political scientists (Fadeev, 2004; Sabirova, 2005; Kuzmin, 2001; Shumilina, 2009). Sabirova (2005) gives a comprehensive analysis of relationship models of Russian corporations and government in the post-Soviet period. The author regarded the Soviet system as a kind of state corporatism. Of the same opinion was a famous Russian scientist and economist S. Kuzmin (2001) who assumed that the basis of "corporate capitalism" in Russia had to form financial and industrial corporations, the introduction of which was facilitated by the fact that in the Soviet times there were powerful state monopolies by type of Gazprom.

Shumilina's dissertation (2009) shows that the emergence and development of various types of corporations - not only companies but religious, professional, regional and other allied organizations - will be "a natural result of the formation of a civil society".

\subsection{Opinions of Foreign Scientists about the Formation and Development of Russian Corporations}

In the second half of the $20^{\text {th }}$ century in the Western historical and legal science there was a marked interest in the economic history of Russia in the period of capitalist development of the $19^{\text {th }}-20^{\text {th }}$ centuries. Among the works of foreign authors there should be mentioned some papers by German scientists - Z. fon Vaiher, E. Amburger, K. Heller (1998), American scientists - J. McKay (1970), A. Rieber (1987), A. Chayndler (1977), F. Carstensen (1984) - dedicated to the functioning of both Russian and foreign companies in Russia.

In his famous work Pioneers for Profit: Foreign Entrepreneurship and Russian Industrialization, 1885-1913 American researcher J. McKay (1970) described the activities of foreign companies in various sectors of Russian industry. Next was another American historian, Alfred J. Rieber (1987), who drew attention to the fact that foreign joint stock companies in Imperial Russian enjoyed more favourable conditions than those that belonged to Russian citizens.

American history professor Thomas Owen in 1995 published a monograph on the history of organization and activities of Russian corporations over a long-term historical perspective. He drew attention to the two main forms of organization of companies with collective owners: a joint stock company and a trading house as a combination of western practices and national traditions.

In foreign legal literature the beginning of the $21^{\text {st }}$ century was noted by a significant interest in comparing different systems of corporate governance. In their joint work The End of History for Corporate Law American 
researchers Henry Hansmann and Reinier Kraakman (Hansmann \& Kraakman, 2001) found out that the origins of unification of corporate law were rooted at the end of the $19^{\text {th }}$ century, that is when the largest business entities were corporate in form in the most economically developed countries (they considered Russia to be one of them).

\section{Discussions}

Of particular interest are the works of polemical character that discuss the issue of the time when first corporations in Russia appeared. Historians have three points of view: some of them stick to the version of the origin of craft and merchant corporations already in ancient Russia, others say that they date back only to the Moscow period $-15-16^{\text {th }}$ centuries, and the third group claims that guild organization and merchant corporation in the form of guild in Russia were introduced only on the basis of the decree of Peter I (Pajitnov, 1952; Shubnikov, 2001). However, none of them were able to prove the rectitude of their point of view. The first point of view was held by M. Tikhomirov (1946), B. Rybakov (1948), and V. Stoklitskaya-Tereshkovich (1951). They came to the conclusion that in Russia the elements of craft corporations arose under similar conditions as in the West, i.e. in the period of forming of feudal organization of society. Organizational and legal form of the guild system was introduced later under Peter I in the first quarter of the $18^{\text {th }}$ century. According to other researchers (Yanin, 1996), workshops could appear only when there was a high level of commodity production and specialization. In Russia, the craft was of mostly patrimonial character, which, in turn, prevented the creation of independent craft corporations because of the dependence of many artisans from patrimonial boyar on whose land many city trading quarters were situated. All this prevented the consolidation of artisans by profession.

In their research, B. Rybakov (1948) and M. Tikhomirov (1946) argued that some elements that were typical of guilds existed in Kievan Rus. However, according to the modern historian V. Barsukov (2000), "presence of one or more elements of a guild organization while other signs were absent could not be the evidence of the existence of guilds". A guild corporation had to have an administration body that would monitor the process of production and marketing, which had to be restated in guild charters. But Kievan Rus was not familiar with statutory practice except for princes'statutes.

One of the association forms of Russian merchants for conducting trade in the $13^{\text {th }}-17^{\text {th }}$ centuries has traditionally been considered to be a partnership based on the contract of clubbing. The appearance of clubbing and making it legal Professor T. Novitskaya (1996) applied only to the end of the $16^{\text {th }}$ - early $17^{\text {th }}$ centuries (Novitskaya, 1996). However, the Soviet historian M. Tikhomirov (1946) and the modern researcher V. Momotov (1998) noted that in Articles 48, 49 of the Extensive Edition of Russian Pravda there were mentioned merchant's trust, trade and clubbing partnership.

Foreign researchers have developed two viewpoints on the appearance in Russia corporations - trading companies - capitalist in nature. Some believe that they date back to not earlier than the first quarter of the $18^{\text {th }}$ century, arguing that in the $16^{\text {th }}-17^{\text {th }}$ centuries it could relate to foreign companies, namely the British company Muscovy and the Armenian company located in Persia. In Russia, in their opinion, the main entrepreneur was the state itself, for the most part, in order to satisfy their own needs for iron, weapons, ships, etc. (Baron, 1983). Other researchers also recognize the fact that in Russia trade corporations appeared in the $16^{\text {th }}$ century represented by "guests", guest and cloth hundreds (Fuhrmann, 1972; Bushkovitch, 1975).

Another group of scientists says that corporations in Russia appeared only in $19^{\text {th }}$ century when their status was determined by law. However, according to the Soviet civil scholar A. Goykhbarg (1927) lack of legal regulation of the organization and activities of a person before the law did not mean absence of the subject. This position is supported by modern Russian scientists. According to V. Gorlov (1998), first joint-stock companies in Russia appeared in the $17^{\text {th }}$ century. So, it should not be argued that "these entities could have arisen only in the $19^{\text {th }}$ century with the introduction of the laws governing their activities".

Whether the corporations were independent participants in civil relations or a means to implement government policy is a matter of long-term scientific dispute. A striking example of this were the research papers devoted to the activities of the well-known Russian-American Company published by Soviet historians S. Okun (1939), N. Bolkhovitinov (1998), modern researchers A. Yermolayev (2000), A. Petrov (2006), as well as foreign authors Eadem (1987); Gibson (1976), Mazour (1944), Dmitrishin (1993). The most controversial for them were the questions: What role did this company play in the realization of the colonial plans of Russia? What was the relationship between the managers of the Russian-American Company with the tsarist government? There are two opposing positions in this issue. One of them was expressed by the company's official historian A. Tikhmenev (1861-1863), who pointed out the partnership nature of company and the Russian government. Another position was taken by the Soviet historian S. Okun (1939). He claimed that the Russian-American 
company could be considered solely a state-owned enterprise with which the Russian government intended to implement the expansionist plans and achieve a dominant position on the west coast of North America. B. Dmitrishin (1993), an American historian, shared the view of S. Okun. However, the modern historian A. Petrov (2006), managed to prove that for almost 70 years of the activity of the Russian-American Company the tsarist government did not manage to turn it into a part of state machinery and was used only as a means to implement its foreign policy goals.

\section{Conclusion}

The methodological error of many researchers is that they turn, generally, to the past from the present instead of going from the past to the present, and thus achieving more accurate and historical understanding (Khayrutdinov, 2014).

When studying historical and legal issues dogmatization should be carefully avoided (Kovaleva, et al, 2015).

Due to the fact that the study of history and development of corporations was uneven, there is a need for an evidence-based periodisation. Whatever full development a legal institution might have achieved at a specific historical moment, it is the result of previous development of the relationships it dealt with and at the same time carries the seeds of future modifications.

Corporations attract researchers of different sciences that explore them using their own methodological approaches. We can agree with the need for lawyers to study the economic factors that play a leading role in the formation of legal institutions, and for economists not to neglect the legal structure of the studied economic phenomena.

Approaches of economists and lawyers to analyze historical events differ in the close attention to the institutional component of the changes in corporate organization of partnerships and new corporate combinations. In contrast, historians work differently - they are interested primarily in archival material (Gafiyatullina, et al, 2015).

Objectively, there is a need to bring together all scientists who study the phenomenon of the corporation, and establish a tradition of international forums in order to identify key aspects of debate on topical issues of organization and activities of corporations, the emergence of new forms of corporate associations of people in different spheres of public life and their development prospects.

\section{Acknowledgments}

The work is performed according to the Russian Government Program of Competitive Growth of Kazan Federal University

\section{References}

Amfiteatrov, G. (1930). Osnovnyye nachala grazhdanskogo zakonodatelstva i borba za marksistskuyu metodologiyu. [The basic principles of Civil Law and the Struggle for Marxist Methodology]. Soviet State and Revolution, 4, 72-77.

Bakhchisaraytsev, Kh. E. (1927). Materialy k voprosu o yuridicheskoy prirode aktsionernykh obshchestv s uchastiyem goskapitala $\mathrm{v}$ SSSR [Materials on the question of the legal nature of joint-stock companies with the participation of state capital in the USSR]. Sovetskoye Pravo, 2(26), 101-122.

Baron, C. H. (1983). Entrepreneurs and entrepreneurship in sixteenth/seventeenth century Russia. In G. Guroff, \& F. Carstensen (Eds.), Entrepreneurship in Imperial Russia and the Soviet Union (pp. 27-58). Princeton, New Jersey. http://dx.doi.org/10.1515/9781400855285.27

Barsukov, V. L. (2000). Soslovno-korporativnyye, predstavitel'nyye i politicheskiye organizatsii predprinimateley dorevolyutsionnoy Rossii. [Class and Corporate, Representative and Political Organisations of Entrepreneurs in Pre-Revolutionary Russia]. Novosibirsk, 87.

Belonovskaya, A. M. (2010). Stanovleniye i razvitiye artel'noy formy sobstvennosti i organizatsii truda v Rossii (vtoraya polovina XIX - nachalo KHKH v.) [Formation and Development of Artisanal Forms of Ownership and Organization of Labour in Russia (second half of thw $19^{\text {th }}$ - early $20^{\text {th }}$ entury)]. (Doctoral dissertation). Moscow, 173.

Biyushkina, N. I., \& Grachov, D. V. (2007). Pravovoye regulirovaniye sindikatov v sovetskoy Rossii v period NEP. [Legal Regulation of Syndicates in Soviet Russia during the NEP]. Bulletin of Nizhny Novgorod University named after N.I. Lobachevsky, 3, 188-198.

Bolkhovitinov, N. N. (1998). Stanovleniye i razvitiye russko-amerikanskikh otnosheniy, 1732-1867. [Formation and Development of Russian-American Relations, 1732-1867]. Moscow, 347. 
Bushkovitch, P. (1975). The merchant class of Moscow 1580-1650 (Doctoral dissertation). Columbia University, 236.

Carstensen, F. V. (1984). American Enterprise in Foreign Markets: Studies of Singer and International Harvester in Imperial Russia. Chapel Hill, 67.

Chandler, A. (1977). The Traditional Enterprise in Commerce. Cambridge, Mass, 172.

Chernozhukov, M. V. (2001). Razvitiye aktsionernogo prava v Rossii v XIX - XX vv. (1805-1917): istoriko-pravovoye issledovaniye. [The Development of Company Law in Russia in the $19^{\text {th }}-20^{\text {th }}$ centuries. (1805-1917): historical and legal research]. (Doctoral dissertation). Nizhny Novgorod, 206.

Dmitrishin, B. (1993). Administrativnyy apparat Rossiysko-amerikanskoy kompanii, 1798-1867. [The administrative staff of the Russian-American Company, 1798-1867]. American Yearbook. Moscow, 90-99.

Eadem, (1987). The Russian American Company and the Imperial Government. In S. F. Starr (Ed.), Russia's American colony (pp. 43-64). Durham.

Fadeyev, K. V. (2004). Osobennosti formirovaniya i realizatsii politicheskikh interesov promyshlennykh korporatsiy $v$ sovremennoy Rossii./Features of Formation and Implementation of Political Interests of Industrial Corporations in Modern Russia]. (Doctoral dissertation). Ufa, 181.

Florya, B. N. (1977). Privilegirovannoye kupechestvo i gorodskaya obshchina v Russkom gosudarstve (pervaya polovina XVI - nachalo XVII v.). [Privileged Merchants and Urban Communities in the Russian State (first half of the $16^{\text {th }}$ - early $17^{\text {th }}$ centuries.). History of the USSR, 5, 151-157.

Fuhrmann, J. (1972). The Origins of Capitalism in Russia. Chicago: 346.

Funk, Ya. I., Mikhalchenko, V. A., \& Khvaley, V. V. (1999). Aktsionernoye obshchestvo: istoriya i teoriya. [Company: History and Theory]. Minsk, 607.

Gafiyatullina, A. Z., Nikonova, T. V., Vagin, S. G., Kharisova, R. R., Pavlova, E. I., Khayrutdinov, R. R., \& Ishmuradova, I. I. (2015). Organization of Controlling the Intellectual Potential of Company Personnel. Review of European Studies, 7(4), 13-19. http://dx.doi.org/10.5539/res.v7n4p13

Gibson, J. (1976). Imperial Russia in Frontier America. New York, 342.

Glazov, Yu. V. (2011). Razvitiye kupecheskogo prava v Rossii v XVIII veke. [Development of Merchant Law in Russia in the $18^{\text {th }}$ century]. Scientific notes of Kursk State University, 4, 35-44.

Glazov, Yu. V. (2013). Institutsionalizatsiya gildeyskoy organizatsii kupechestva v Rossii v pervoy treti XVIII veka. [Institutionalization of the Merchants Guild Organization in Russia in the First Third of the $18^{\text {th }}$ century]. History of State and Law, 7, 54-56.

Golikova, N. B. (1998). Privilegirovannyye kupecheskiye korporatsii Rossii XVI - XVIII v. [Privileged Merchant Corporations in Russia in the $16^{\text {th }}-18^{\text {th }}$ centuries]. Moscow, 524.

Gorlov, V. (1998). Pravovoye polozheniye obshchestv s ogranichennoy otvetstvennostyu. [Legal Status of a Limited Liability Company]. (Doctoral dissertation). Ekaterinburg, 167.

Goykhbarg, A. (1927). Ocherki khozyaystvennogo prava. [Essays on Commercial Law]. Moscow, 302.

Gurevich, G. S., \& Rokhmistrov, S. N. (2004.) Korporativnoye upravleniye: istoki stanovleniya $v$ Rossii. [Corporate Management: Formation Origins in Russia]. Moscow, 144.

Hansmann, H., \& Kraakman, R. (2001). The End of History for Corporate Law. GEO. L. 89, 439-468.

Isayev, I. A. (1977). Pravovyye voprosy ispol'zovaniya chastnogo kapitala v vosstanovlenii sovetskogo narodnogo khozyaystva (1921-1925). [Legal Issues of Using Private Capital in the Restoration of the Soviet Economy (1921-1925)]. Moscow, 51.

Izmestyeva, T. F. (1998). Postroyeniye modeli funktsionirovaniya inostrannykh korporatsiy v Rossii v period industrializatsii $v$ kontse XIX - nachale XX vv. [Building a model of the functioning of foreign companies in Russia in the period of Industrialization in the late $19^{\text {th }}$ - early $20^{\text {th }}$ centuries]. Economic History. Review. Vol. 2 - Moscow, 47-63.

Khayrutdinov, R. R. (2014). Museum Conference of 1926 in Kazan. World Applied Sciences Journal, 31(2), 193-195.

Kheller, K. (1998). Otechestvennoye i inostrannoye predprinimatel'stvo v Rossii XIX - nachala XX veka. [Domestic and Foreign Business in Russia in the $19^{\text {th }}$ - early $20^{\text {th }}$ century]. National History, 4, 55-65.

Kovaleva, N. I., Valeyeva, N. Sh., Avilova, N. L., Kharisova, G. M., Khayrutdinov, R. R., Khairullina, E. R., \& Shaikhlislamov, A. K. (2015). Recommended Practices for Improving the Competitiveness of the Russian 
Education Services Market under the Conditions of the International. Review of European Studies, 7(4), 1-5. http://dx.doi.org/10.5539/res.v7n4p1

Krasilnikova, T. K. (2001). Pravovoy status aktsionernykh obshchestv v Rossii v XIX - nachale XX vekov (istoriko-pravovoy aspekt). [The Legal Status of Joint-Stock Companies in Russia in the $19^{\text {th }}-$ early $20^{\text {th }}$ Centuries (historical and legal aspect)]. (Doctoral dissertation). Saratov, 236.

Kurys, N. V. (2003). Inostrannyye investitsii: Rossiyskaya istoriya (pravovoye issledovaniye). [Foreign Investment: Russian History (legal research)]. St. Petersburg, 216.

Kushniruk, A. S. (2005). Osnovnyye zakonomernosti stanovleniya i razvitiya aktsionernogo prava $v$ Rossii. [Basic Laws of Formation and Development of Company Law in Russia]. (Doctoral dissertation). Moscow, 201.

Kuzmin, S. A. (2001). Zanyatost: strategii Rossii. [Employment: Strategy of Russia]. Moscow, 129.

Landkof, S. N. (1924). Tovarishchestva s ogranichennoy otvetstvennostyu na Zapade $i v$ SSSR. [A limited liability company in the West and the USSR]. Kharkov, 39.

Laverychev, V. Ya. (1982). Gosudarstvo i monopolii $v$ dorevolyutsionnoy Rossii. [State and Monopoly in Pre-Revolutionary Russia]. Moscow, 200.

Malykhina, M. N. (2003). Istoriko-pravovoy analiz stanovleniya korporativnykh form khozyaystvovaniya. [Historical and Legal Analysis of the Formation of Corporate Forms of Management]. Rostov-on-Don, 28.

Mazour, A. G. (1944). The Russian-American Company: Private or Government Enterprise? Pacific Historical Review, XIII, 97-108. http://dx.doi.org/10.2307/3634611

McKay, J. P. (1970). Pioneers for Profit: Foreign Entrepreneurship and Russian Industrialization, 1885 -1913. Chicago, 422. http://dx.doi.org/10.7208/chicago/9780226559926.001.0001

Mironov, B. N. (2003). Sotsialnaya istoriya Rossii perioda imperii (XVIII - nachalo XX v.). [Social History of Russian Empire period ( $18^{\text {th }}-$ early $20^{\text {th }}$ centuries). St. Petersburg, T. 1.2, 548, 583.

Momotov, V. V. (1998). Iz istorii stanovleniya dogovora skladnichestva v russkom srednevekovom prave. [Glimpses of History of the Formation of the Clubbing Contract in Russian Medieval Law]. Krasnodar, 18.

Nosov, S. I. (2001). Aktsionernoye zakonodatel'stvo Rossii: opyt teoreticheskogo i istoriko-pravovogo issledovaniya. [Russian Company Law: Experience of the Theoretical, Historical and Legal Research]. (Doctoral dissertation). Moscow, 350.

Novitskaya, T. Ye. (1996). Nekotoryye aspekty pravovogo regulirovaniya ekonomiki v Drevnerusskom gosudarstve. [Some Aspects of Legal Regulation of the Economy in the Ancient Russian State]. Vestnik MGU. Episode 11, 47-51.

Okun, S. B. (1939). Rossiysko-amerikanskaya kompaniya. [Russian-American Company]. Moscow, 189.

Osnovy ucheniya o tovarishchestvakh $i$ aktsionernykh obshchestvakh. [Fundamentals of Partnerships and Joint-Stock Companies]. Moscow, 168.

Owen, T. (1995). Russian Corporate Capitalism from Peter the Great to Perestroika. N.Y. Oxford, 309.

Pazhitnov, K. A. (1952). Problema remeslennykh tsekhov v zakonodatel'stve russkogo absolyutizma. [Problem of Guilds in the Legislation of Russian Absolutism]. Moscow, 211.

Petrov, A. Yu. (2006). Rossiysko-amerikanskaya kompaniya: khozyaystvennaya deyatelnost na otechestvennom $i$ zarubezhnom rynkakh: 1799-1867 gg. [Russian-American Company: Economic Activity in the Domestic and Foreign Markets: 1799-1867 gg.] (Doctoral dissertation). Moscow, 478.

Potkina, I. V. (1997). Zakonodatel'noye regulirovaniye predprinimatel'skoy deyatel'nosti inostrantsev v Rossii. 1861-1916 gg. [Legislative Regulation of Business Activities of Foreigners in Russia. 1861-1916.] Foreign business and foreign investment in Russia. Moscow, 19-33.

Rieber, A. (1987). Merchants and Entrepreneurs in Imperial Russia. University of North Carolina Press Chapel Hill, 464.

Rukavishnikov, S.M. (2005). Korporatsiya kak pravovoy i sotsialnyy institut. [Corporation as a Legal and Social Institution]. (Doctoral dissertation). Moscow, 165.

Rybakov, B. A. (1948). Remeslo Drevney Rusi. [Craft of Ancient Russia]. Moscow, 803.

Sabirova, L. M. (2005). Vzaimootnosheniya korporatsiy $i$ vlasti $v$ postsovetskoy Rossii. [Corporations and Government Relationships in Post-Soviet Russia]. (Doctoral dissertation). Ufa, 174. 
Serova, O. A. (2011). Teoretiko-metodologicheskiye i prakticheskiye problemy klassifikatsii yuridicheskikh lits sovremennogo grazhdanskogo prava Rossii. [Theoretical, Methodological and Practical Problems of Classification of Legal Entities of the Modern Civil Rights in Russia]. (Doctoral dissertation). Moscow, 328.

Shubnikov, Yu. B. (2002). Stanovleniye i razvitiye pravovogo obespecheniya predprinimatel'skoy deyatel'nosti v Rossii XIX - nachalo XX vekov (istoriko-teoreticheskoye issledovaniye). [Formation and Development of Legal Support Business in Russia in the $19^{\text {th }}$ - early $20^{\text {th }}$ Centuries (Historical and Theoretical Study)]. (Doctoral dissertation). St. Petersburg, 342.

Shumilina, A. B. (2009). Politiko-pravovyye tekhnologii obespecheniya korporativnykh interesov v Rossii. [Political and Legal Technologies of Corporate Interests in Russia. (Doctoral dissertation)]. Rostov-on-Don, 155.

Smirnov, S. A. (2002). Pravovoye regulirovaniye inostrannogo predprinimatel'stva v Rossii vo vtoroy polovine $X I X$ - nachale XX vekov. [Legal Regulation of Foreign Business in Russia in the Second Half of the $19^{\text {th }}$ early $20^{\text {th }}$ centuries]. (Doctoral dissertation). Volgograd, 164.

Sonkin, N. (1999). K voprosu stanovleniya rossiyskogo korporativnogo prava. [On the Question of Formation of the Russian Corporate Law]. Russian Lawyer, 3(23), 5-22.

Sonkin, N. B., \& Gromkovskaya, T. S. (1989). Mezhotraslevyye nauchno-tekhnicheskiye kompleksy v novykh usloviyakh khozyaystvovaniya (ekonomiko-pravovoy aspekt). [Interbranch Scientific and Technical Complexes in the New Economic Conditions (Economic and Legal Aspects). Kharkov, 62.

Sovmestnyye predpriyatiya, mezhdunarodnyye ob"yedineniya i organizatsii na territorii SSSR. (1989). [Joint Ventures, International Associations and Organizations on the Territory of the USSR (1989)]. Ed. GD Golubova. Moscow, 542.

Stoklitskaya-Tereshkovich, V. V. (1951). Problema mnogoobraziya srednevekovogo tsekha na Zapade i na Rusi. [The problem of Diversity of Medieval Shop in the West and in Russia]. Middle Ages, 3, 69-71.

Tikhmenev, P. (1861-1863). Istoricheskoye obozreniye obrazovaniya Rossiysko-Amerikanskoy kompanii $i$ deystviy yeyo do nastoyashchego vremeni. [Historical Survey of Education of the Russian-American Company and its Operations to Date]. T.1-2. St. Petersburg, 388.

Tikhomirov, M. N. (1946). Remeslennyye obyedineniya v Kiyevskoy Rusi. [Craft associations in Kievan Rus]. Scientists Notes of Moscow State University, 87, 22-37.

Volnyanskiy, D. A. (2010). Teoreticheskiye problemy korporativnogo prava RF. [Theoretical problems of corporate law of the Russian Federation]. (Doctoral dissertation). Omsk, 182.

Vorms, A. (1922). Smeshannyye aktsionernyye obshchestva. [Mixed Joint-Stock Companies]. Soviet Law, 1, 89-99.

Voznesenskaya, N. N. (1989). Sovmestnyye predpriyatiya kak forma mezhdunarodnogo ekonomicheskogo sotrudnichestva. [Joint Ventures as a Form of International Economic Cooperation]. Moscow, 283.

Yanin, V. L. (1996). Novgorod kak sotsial'naya struktura. [Novgorod as a social structure]. Feudal lords in the city: the West and Russia. Moscow, 42-67.

Yermolayev, A. N. (2000). Rossiysko-amerikanskaya kompaniya $i$ imperatorskoye pravitel'stvo. [Russian-American Company and the Imperial Government]. (Doctoral dissertation). Kemerovo, 220.

Yerokhina, O. V. (2009). Zakonodatel'noye regulirovaniye monopolisticheskikh ob"yedineniy v Rossiyskoy imperii v kontse XIX - nachale XX v. [Legislative Regulation of Monopolies in the Russian Empire in the late $19^{\text {th }}$ - early $20^{\text {th }}$ century]. Urgent problems of Arts and Sciences, 12, 69-73.

Zolotarov, V. S. (1983). Nauchno-proizvodstvennyy kompleks razvitogo sotsializma. [Research and Production Complex of Developed Socialism]. Rostov, 150.

\section{Copyrights}

Copyright for this article is retained by the author(s), with first publication rights granted to the journal.

This is an open-access article distributed under the terms and conditions of the Creative Commons Attribution license (http://creativecommons.org/licenses/by/3.0/). 